\title{
УЛОГА ФЕНОМЕНОЛОШКОГ СТАВА У ПРОБЛЕМУ ДРУШТВЕНЕ СТВАРНОСТИ АЛФРЕДА ШИЦА
}

\begin{abstract}
Anстракт: У раду се учење аустријског теоретичара Алфреда Шица (Alfred Schutz), изложено у текстовима првог тома његових сабраних дела, сагледава из перспективе улоге коју у њему има Хусерлов (Edmund Husserl) феноменолошки став. Заступајући важност анализе структуре света свакодневног живота у својој феноменологији природног става, Шиц користи различите теоријске домете Хусерлове феноменологије, не посвећујући притом посебну пажњу самом феноменолошком ставу. Због тога се у раду разматра у којој мери Шицово разумевање природног става и њему одговарајућег света зависи од овог аспекта Хусерлове филозофије, са посебним освртом на тезе аустријског теоретичара изложене у спису „О вишеструким стварностима“. Након показивања да се Хусерлов феноменолошки став не може повезати са „ставом научне теорије“ о коме се говори у тексту о вишеструким стварностима, у раду се изостанак разматрања трансценденталног става у Шицовом учењу заоштрава излагањем Нејтенсонове (Maurice Natanson) критике овог учења. У раду се затим разматра у којој мери се аустријски теоретичар удаљавањем од трансценденталне феноменологије приближава прагматистичкој филозофији. Коначно, извесно решење проблема одговарајућег позиционирања феноменолошке филозофије у Шицовој теорији тражи се у Еберлијевим (Thomas S. Eberle) ставовима о Лукмановом (Thomas Luckmann) разликовању феноменологије и социологије. Рад се закључује разматрањем могућности говора о „ставу феноменолошке филозофије“ у Шицовом систему вишеструких стварности.
\end{abstract}

Кључне речи: Алфред Шиц, феноменологија, природни став, феноменолошки став, Едмунд Хусерл, Проблем друштвене стварности

\section{Увод - искуство свакодневног живота и његова улога у Шицовој филозофији}

На самом почетку „Увода“ првог тома сабраних дела аустријског теоретичара Алфреда Шица (Alfred Schutz), Морис Нејтенсон (Maurice Natanson), уредник овог тома, истиче да је најважнији мотив Шицовог теоријског рада

\footnotetext{
${ }^{1}$ dusan.milenkovic@filfak.ni.ac.rs
} 
његово истрајно испитивање „структуре света свакодневице“ (Natanson 2012a: 21). Иако приређен према Шицовој сопственој замисли, а не на основу Нејтенсонових уредничких интервенција (Natanson 2012б: 17), први том Шицових сабраних дела под називом „Проблем друштвене стварности“ несумњиво потврђује овај Нејтенсонов став, будући да се у сваком од текстова обједињених у овом издању - чак и у онима који нису директно усмерени ка овој теми, као што је то случај са текстовима о Шелеровом (Max Scheler) и Сартровом (Jean-Paul Sartre) разумевању интерсубјективности - разматрају проблеми који се тичу начина на који се одвија човеков искуствени живот у околностима свакодневног живота (Шиц 2012: 221-226, 257-258). Аустријски теоретичар на различите начине у текстовима првог тома сабраних дела упућује на свакодневни живот као почетну тачку промишљања конкретних проблема који се тичу односа једне свести и окружења у коме се одвијају њене активности. Он користи уобичајену феноменолошку терминологију и говори о „природном ставу“ према свету свакодневице, али се служи и кључним појмом касније Хусерлове (Edmund Husserl) филозофије и указује на „свет живота“ једне свести. У текстовима првог тома сабраних дела, Шиц непосредни предмет свог теоријског интересовања именује и другачијим терминима. Неки од ових термина буде директније асоцијације ка Шицовом сопственом учењу, попут „света чињења“, којим Шиц исказује намеру да одношење свести према свету свакодневног живота објасни из перспективе различитих облика понашања субјекта (Шиц 2012: 65-80, 264-268, 280-287). У другим случајевима, аустријски теоретичар изједначује природни став са „здраворазумским мишљењем“, ,здраворазумским искуством“" и томе слично (Шиц 2012: 51-60, 103-105, 106). У раду ћемо се примарно служити термином „природни став“, док ћемо се на „свет живота“ осврнути у каснијим поглављима рада.

Различита теоријска решења аустријског феноменолога (попут сугерисане важности „чињења“ као примарне активности свести у свакодневном животу) указују на значај који теоријско промишљање света свакодневног живота и њему одговарајућег природног става ужива у Шицовој концепцији. Он се може представити и уколико се сагледа однос који Шиц успоставља између света свакодневног живота и других ,алтернативних стварности“ о којима говори у текстовима првог тома сабраних дела, а посебно у познатом тексту „О вишеструким стварностима“. За разматрање значаја који Шиц придаје структури свакодневног живота интересантна је и чињеница да је поменути текст подељен на два готово једнака дела. У првом делу текста, реч је о свакодневном животу као о „врховној стварности“ унутар које се одвија највећи део човековог искуственог живота, док се у другом говори о алтернативним стварностима, односно, „омеђеним областима значења“ којима, између осталог, припадају специфични домени снова, фантазије, уметности, хумора, игре, религије и науке (Шиц 2012: 264-287, 287-317). Не посвећујући сваком од поменутих алтернативних светова подједнаку пажњу, аустријски теоретичар се у поменутом тексту концентрише на неке од омеђених области значења у којима налази важне карактеристике уз помоћ којих се могу објаснити разлике између света свакодневног 
живота и других домена стварности. Након општијег разматрања такозваног „света илузије“ (који заправо представља назив за групу разноврсних алтернативних светова која обухвата свет фантазије, али и „домен дневног сањарења, игре, фикције, бајки, митова и шала“), а затим и „света снова“ (Шиц 2012: 292, 298-303), Шицово интересовање се у поменутим текстовима окреће и ка теми коју у овом тексту сматра најважнијом. То је теоријско промишљање „свету научне теорије“" и начина на који се искуство свакодневног живота разликује од става „непристрасног посматрача““ који приписује научнику (Шиц 2012: 292, 303-317). С обзиром на то да у Шицовој теорији свет свакодневног живота има статус „врховне стварности“, ове алтернативне стварности треба сагледавати као својеврсне „модификације“ основних карактеристика света свакодневног живота и њему одговарајућег природног става. Свакодневни живот тако одликују „потпуна будност“ и „пуна пажња усмерена ка животу“, али и друге карактеристике, које се тичу веровања у објективно постојање света, чињења као основног облика интеракције са светом, разумевања сопствене свести као сопства, као и прихватања интерсубјективности и „стандардног времена“ (Шиц 2012: 288, 291).

Иако говори о бројним алтернативним стварностима са којима субјект искуства може доћи у додир различитим „напетостима свести“ (Шиц 2012: 269), у Шицовим текстовима обједињеним у првом тому сабраних дела најмање се речи може наћи о „феноменолошком ставу“. Међутим, у Хусерловом феноменолошком учењу, управо је овај став примарна алтернатива природном ставу и начин на који се његова теоријска концепција окреће анализи садржаја одређеног искуства мимо веровања у објективно постојање света као предмета тог искуства (Husserl 1975: 18-21, 59-61). Посебно је изненађујућа околност то што аустријски филозоф не посвећује довољно пажње оном ставу који, према Хусерловом мишљењу, свест мора да заузме да би уопште и започела са феноменолошким теоретисањем (Husserl 1975: 67-70). Задржавајући се на повременим указивањима на трансцендентални став у Хусерловој феноменологији (при чему ћемо се на нека од њих осврнути у наставку текста) (Шиц 2012: 154-157, 173-174, 286), Шиц у првом тому сабраних дела не обрађује подробно сам феноменолошки став и улогу коју он има у његовом учењу ни у оним текстовима у којима би се то непосредно очекивало. Он то не чини у довољној мери ни у тексту о вишеструким стварностима, у коме се анализира читав низ различитих „напетости свести“, ни у радовима директно посвећеним феноменолошком наслеђу, као што су текстови „Неки водећи појмови феноменологије“, „Феноменологија и друштвене науке“ и „Хусерлов значај за друштвене науке“. Такође, зачуђујуће је и што се у литератури посвећеној Шицовом учењу не може наћи пуно речи о његовом избегавању да се на одговарајући начин позабави питањем феноменолошког става. Док се у литератури обично истиче његово промовисање феноменолошког наслеђа и напор да се теоријско подручје феноменологије прошири и у правцу разматрања проблема̂ друштвених наука, о Шицовом отклону од Хусерлове филозофије евентуално се говори из перспективе његовог одбацивања начина на који Хусерл покушава да реши 
проблем интерсубјективности (Embree 2020; Barber 2020; Kim 2005, 205-206). Иако се не тиче директно проблема феноменолошког става, Шицова критика Хусерловог покушаја да феноменолошки обради специфично искуство друге свести може се индиректно повезати и са проблемом феноменолошког става, као што ћемо покушати да покажемо у наставку рада.

Важне тезе о проблематичном Шицовом одношењу према Хусерловој трансценденталној феноменологији и феноменолошком ставу налазимо у текстовима Алексиса Емануела Гроса (Alexis Emanuel Gros) и Стивена Веиткуca (Steven Vaitkus) (Gros 2017: 220, 228-229, 231-232; Vaitkus 2005, 100-105). Међутим, посебно интересантан пример отвореног говора о изостанку Шицовог тематизовања феноменолошког става налазимо у једном тексту већ поменутог Мориса Нејтенсона, па ћемо се њиме детаљније позабавити у раду (Natanson 1970: 114-117). Ипак, без обзира на то што се у литератури о Шицовој теоријској концепцији не могу тако често наћи тезе о његовом ограђивању од феноменолошке теорије, поменимо и то да је сам Шиц у писму Арону Гурвичу (Aron Gurwitsch) 1956. године испољио одређену сумњу у компатибилност свог учења са изворним обликом Хусерлове феноменологије, па нам ова околност представља и посебан повод за разматрање ове проблематике (Gros 2017: 232; Vaitkus 2005: 105).

Чак и мимо начина на који се сам Шиц и аутори текстова о његовом учењу односе према извесном занемаривању феноменолошког става у његовој „феноменологији природног става“, може се издвојити неколико разлога у прилог очекивању да се аустријски филозоф одреди и према овом познатом мотиву феноменолошке теорије. У наставку текста ћемо се позабавити овим разлозима.

\section{Феноменолошки став у Шицовој теоријској концепцији}

Најпре се може истаћи да већ и само Шицово учестало упућивање на „природни став“ као начин одношења свести према свету свакодневног живота подразумева „феноменолошки став“ као своју супротност. У Хусерловој теоријској концепцији, „природни став“" и свет који њему одговара као такав добија смисао тек у одговарајућем односу према „феноменолошком ставу“ (Husserl 1975: 59-61; Vaitkus 2005: 102-103). Шицово упућивање на „природни став" лишено је одговарајуће теоријске конотације уколико се оно спроводи мимо указивања на одговарајућу алтернативу - у овом случају, оличену у специфичном начину на који се свест у феноменолошком ставу односи према садржају свог искуства независно од веровања у објективно постојање предмета искуства (Natanson 1970: 119). Тек из перспективе „нововрсног, трансценденталног искуства“ које се отвара феноменолошким ставом (Husserl 1975: 21), природни став се открива свести као такво одношење према свету које подразумева више од онога што је тој свести дато у самом искуству. Међутим, лишен значења које добија у односу на феноменолошки став као одговарајућу алтернативу, „Природни став“ би се у Шицовом учењу евентуално могао односи- 
ти на нерефлектовану уроњеност свести у њену сопствену „живу садашњост“ (Шиц 2012: 272-273). Ипак, чак и у случају да Шиц заиста користи уврежени феноменолошки термин „природни став“ за шире именовање нерефлектованог односа субјекта према свету као конгломерату предмета различитих искустава, његова би употреба познатог Хусерловог термина већ и тада била проблематична. У том случају, она би могла наводити читаоца на лош траг, погрешно му сугеришући да ће се ова нерефлектованост превазићи управо феноменолошком редукцијом (као што је то случај у Хусерловој концепцији). Штавише, Шицова употреба овог термина би читаоца могла оставити и у недоумици поводом тога какав став би свест требало да заузме како би „природни став“ учинила темом теоријског дискурса, а посебно дискурса инспирисаног феноменологијом. О овоме ће више речи бити у наставку рада.

Други проблем који отвара извесно Шицово избегавање да позиционира феноменолошки став у својој теорији - макар се то позиционирање огледало у отвореном ограђивању од овог Хусерловог учења - тиче се чињенице да сам Шиц у три текста првог тома сабраних дела примарну пажњу посвећује феноменолошком наслеђу. О овој традицији и њеној улози у промишљању теоријских проблема који су предмет Шицовог интересовања говори се у текстовима „Неки водећи појмови феноменологије“, „Феноменологија и друштвене науке“ и „Хусерлов значај за друштвене науке“. Уколико нас аустријски теоретичар у три текста аргументовано уверава да се теоријски домети Хусерлове феноменологије могу искористити у промишљању света свакодневног живота и интерсубјективне интеракције у њему (Шиц 2012: 167-168, 173-178, 183 189, 197-201), онда се од Шицове теоријске концепције може очекивати да се на одговарајући начин опходи и према Хусерловим тезама о феноменолошком ставу. Ово је још важније уколико се узме у обзир да родоначелник феноменологије до највећег броја теоријских увида на које Шиц указује управо и долази захваљујући промишљањима које спроводи унутар феноменолошког става. Штавише, сам систем феноменолошке терминологије којим се аустријски филозоф служи у текстовима првог тома сабраних дела задобија одговарајуће значење тек у теоријској концепцији утемељеној на тезама о односу између природног става и феноменолошког става - попут епохеа или апрезентације (о чему ћемо више говорити у наставку). Разуме се, као што смо у раду већ поменули, несумњиво је да Шиц има у виду Хусерлово учење о феноменолошком ставу - он на њега свакако реферише на неколико места у овим студијама, а у тексту „Неки водећи појмови феноменологије“ и објашњава значење овог феноменолошког појма (Шиц 2012: 173-174). Међутим, он пропушта прилику да о овом проблему говори када теоријске домете феноменологије примењује у сопственим промишљањима, која утемељује на Хусерловом теоријском наслеђу.

Надаље, трећи разлог због кога се може сматрати проблематичним Шицово избегавање отвореног говора о феноменолошком ставу у формирању сопствене теоријске концепције директно се тиче његовог учења изложеног у тексту „О вишеструким стварностима“. Хусерлов феноменолошки став, као 
непосредна супротност начину на који се свет, када је реч о његовом објективном постојању, доживљава у природном ставу, није могуће индиректно извести из других теоријских решења које Шиц у овом тексту предлаже, попут начина на који говори о специфичном ставу научника, о коме ћемо убрзо говорити. Са друге стране, сам појам природног става се у тексту о вишеструким стварностима не може извести као непосредна супротност других „омеђених облика значења“, попут светова сна или фантазије. У великом делу поменутог текста, али и у другим текстовима, Шиц овај Хусерлов појам користи независно од својеврсног упоређивања са другим алтернативним стварностима у поменутом тексту, већ га употребљава мимо тог контекста, подразумевајући нијансе значења које је родоначелник у њега уткао. У недостатку отворене теоријске обраде појма природног става, која се посебно очекује у тексту о вишеструким стварностима, читаоцу првог тома Шицових сабраних дела преостаје једино да значење овог појма црпи из хусерловског филозофског наслеђа, супротстављајући га одговарајућем феноменолошком ставу.

Коначно, отворен Шицов говор о феноменолошком ставу у текстовима који су обједињени у књизи о проблему друштвене стварности обелоданио би начин на који се аустријски филозоф опходи према другим теоријским концепцијама на које указује у овим текстовима. Наиме, Шицово избегавање говора о феноменолошком ставу може побудити сумњу у то да се аустријски филозоф ипак удаљава од феноменолошког наслеђа и приближава неким другачијим теоријским концепцијама. Одговарајуће позиционирање Шицовог учења када је реч о његовој верности феноменолошком наслеђу олакшало би и теоријску потрагу за одговарајућим местом које овај теоретичар заузима у историји филозофије и социологије, потрагу коју покрећу одређени тумачи његове теорије (Natanson 1970: 119-120, Eberle 2012: 136-139), али би имало и конкретније предности у разумевању његовог учења. Не само да би нам оно омогућило да мноштво различитих Шицових идеја сагледамо у адекватном контексту (што је сугерисано и претходно поменутим разлозима), већ би нам на посебан начин могло приказати и однос аустријског теоретичара према теоријским концепцијама Џона Дјуија (John Dewey) и Вилијама Џемса (William James). На учења ових теоретичара аустријски филозоф се у више наврата позива (Шиц 2012: 101, 103, 105, 115, 126-127, 160, 263-264, 271, 287), иако су она често сасвим далеко од феноменолошког утемељења његове теорије, па чак и од његових сопствених теоријских решења. Због тога ћемо у наставку рада укратко размотрити и односе које Шицова теоријска концепција успоставља са тим филозофским традицијама, имајући у виду да се у литератури о Шицу могу пронаћи одређене назнаке о извесном удаљавању аустријског филозофа од феноменолошке базе у његовим познијим текстовима (Gros 2017: 223, 231). Сагледавајући у којој мери се ово удаљавање директно тиче изостанка његовог отвореног тематизовања феноменолошког става, у другом делу рада ћемо упоредити одређене теоријске ставове Шицовог учења са Џемсовим и Дјуијевим прагматизмом. 
Феноменолошко наслеђе и теорија о вишеструким стварностима - где потражити феноменолошки став?

Претходно поменуте дилеме поводом начина на који Шиц у својој теоријској концепцији користи феноменолошко наслеђе у промишљању структуре свакодневног живота, као и одговарајућег става који свест заузима према свом окружењу, постају још истакнутије уколико се сагледају из перспективе двају текстова које је аустријски филозоф оригинално објавио исте године. То су текстови „Неки водећи појмови феноменологије“ и „О вишеструким стварностима“. Ако ове Шицове списе из 1945. године већ и на основу самих наслова упоредимо, уочићемо да у њима аустријски филозоф испољава две различите склоности у свом теоријском раду. Прва се огледа у његовој „верности“ феноменолошкој филозофији, а друга представља његову тежњу ка формулисању сопствене, независне теоријске концепције, која превазилази интересовања постављена Хусерловом феноменологијом - као што је теза о вишеструким стварностима. Обрађивањем ових текстова, у наставку рада ћемо покушати да упоредимо ове тенденције Шицовог учења у контексту говора о месту феноменолошког става у теоријској концепцији аустријског филозофа.

Образлажући у тексту о водећим појмовима феноменологије основне тезе овог филозофског усмерења, Шиц указује и на Хусерлову намеру да филозофију уреди по принципима „егзактне“, „строге“ науке, односно „универзалне знаности“" којом ће се утемељити посебни научни подухвати (Шиц 2012: 150; Husserl 1975: 17, 21, 39, 51, 54-56, 67-68). Међутим, изгледа да аустријски филозоф у тексту „О вишеструким стварностима“ сам филозофски дискурс не укључује у домен специфичног научног става према свету. Он феноменолошки чин стављања у заграде објективног постојања света у том тексту најпре помиње приликом представљања сопственог учења о „епохеу природног става“ (Шиц 2012: 286-287). Ипак, ово помињање се у том случају своди на подсећање читаоца на појам феноменолошког епохеа, да би се термин „епохе“ затим искористио за илустровање поменутог „епохеа природног става“, који се огледа у уздржавању од преиспитивања стварности света искуства. Као што смо већ поменули у раду, у наставку текста, представљајући различите алтернативне стварности, односно „омеђене области значења“, аустријски теоретичар посебну пажњу поклања научној контемплацији и специфичностима које карактеришу овај приступ предмету искуства. Међутим, иако као један од циљева текста о неким водећим појмовима феноменологије истиче управо показивање да и сама феноменологија има научни карактер (Шиц 2012: 151-152), у представљању научне контемплације као специфичне напетости свести налазимо другачије Шицове ставове. Он не само да не помиње феноменолошки приступ приликом приказивања различитих делатности којима одговара овакав став свести, већ и научно теоретисање отворено удаљава од начина на који се феноменолог односи према предмету свог истраживања. Наиме, истичући да теоријска контемплација ипак задржава природни став као веру у постојање 
спољашњег света (чиме још једном потврђује „врховност“ стварности свакодневног живота), он изричито, у фусноти 33 у коришћеном издању (Шиц 2012: 307), одбацује феноменолошки епохе, будући да се у додиру са научним садржајима у заграде ставља нешто сасвим друго. Он пре свега говори о томе да у научној делатности треба ставити у заграде „субјективност мислиоца“ и чињеницу да је и сам научник „психофизичко биће“, али и одређена ограничења која намеће свет свакодневног живота, као што су усмереност свести на оне предмете који припадају „свету унутар домашаја“ свести и „фундаментална стрепња“" која диктира одређени спектар сврха којима се свест руководи у том свету (Шиц 2012: 307).

Интересантно је да Шиц у поменутој фусноти, поред ограђивања од феноменолошког епохеа, каже и следеће: „тај термин [природни став, Д. М.] овде се (али не у тексту) употребљава као супротност „феноменолошкој редукцији“ (Шиц 2012: 307). Наведени део ове фусноте није остао незапажен у литератури о Шицовој филозофији. Ту фусноту коментарише Стивен Веиткус у тексту о појму природног става у Шицовом учењу, сматрајући је „изузетно компликованом“" (Vaitkus 2005: 104). Он је објашњава уводећи разлику између два значења појма природног става - природног става као приступа свету који би имале емпиријски оријентисане науке и природног става као начина доживљаја света који би имао човек у свакодневном животу (Vaitkus 2005: 105). Нажалост, Веиткус не посвећује пуно речи самој улози коју би изложена подела имала приликом тумачења текста о вишеструким стварностима, већ се окреће другим проблемима у Шицовом разумевању природног става, па ћемо се у наставку додатно позабавити реченицом из поменуте фусноте.

Најпре није сасвим јасно на шта тачно Шиц циља напоменом да „у тексту“ природни став није супротан феноменолошкој редукцији, али се значење овог става може потражити на једном месту у другом тексту аустријског теоретичара који налазимо у првом тому сабраних дела. Ова напомена би се могла повезати са његовим речима из текста о односу феноменологије и друштвених наука, у коме Шиц говори о „широко распрострањеном неспоразуму“ према коме „,трансцендентална феноменологија оспорава стварно постојање света живота“ (Шиц 2012: 173). Не желећи да представи феноменолога као наивног скептика или феноменалисту (Данси 2006: 177-179), он истиче да за теоретичара овакве оријентације „не постоји сумња да свет постоји и да се манифестује у континуитету хармоничних искустава“ (Шиц 2012: 173). Према оваквом гледишту, „феноменолошка редукција“ није непосредна супротност „природном ставу“, уколико и сам феноменолог верује у постојање спољашњег света (иако га привремено ставља у заграде да би дошао до његове трансценденталне структуре). Међутим, отворено је питање у којој мери се овакво Шицово мишљење заиста може извести из Хусерлове филозофије. Родоначелник феноменологије није тако директан у „Паришким предавањима“ и Картезијанским медитацијама, већ методски, попут Декарта (René Descartes), истиче да редукцију морамо спровести „без обзира да ли свијет постоји или не, или без обзира како се о томе одлучи“" (Husserl 1975: 20, 63-64). 
Независно од проблема усклађивања поменутог гледишта са Хусерловом феноменологијом, поменуту напомену из фусноте смо овде истакли из другог разлога. Наиме, Шиц напомиње да „у тексту“ не користи појам „природног става“ као супротност „феноменолошке редукције““ и то се заиста може сматрати ставом који аустријски филозоф испољава у тексту о вишеструким стварностима. Међутим, изгледа да у датом контексту он превазилази сопствену тежњу ка „уклањању неспоразума“ о томе шта феноменолог чини епохеом. Наиме, изгледа да је овим гестом - одвајањем „природног става“ као термина који се не употребљава „у супротности“ са феноменолошком редукцијом Шиц заправо спровео једно од ретких отворених удаљавања од феноменолошког наслеђа афирмисаног у другим текстовима првог тома сабраних дела. Шиц може релативно безбедно остати у оквиру хусерловске феноменологије која би му обезбедила терминолошку базу за учење које ће представити „феноменологију природног става“. Ипак, он се у реализацији оваквог плана не задржава у домену који му поставља ово филозофско усмерење, па у одређеној инстанци развијања таквог учења „одбацује лестве“ уз помоћ којих је дошао до сложенијих увида које жели да развије, попут теорије о вишеструким стварностима. Управо нам склоност ка оваквом решавању проблема сугерише већ поменуто писмо Арону Гурвичу. Будући да се „вишеструке стварности“ не могу црпети из уске Хусерлове дихотомије природног и феноменолошког става, потребно је да Шиц у одређеној мери испразни појам природног става од стриктне феноменолошке конотације која га чини непосредном супротношћу трансценденталном ставу. Изгледа да се то најефикасније може учинити управо ослабљивањем извесне независности феноменолошког става (која је присутна у изворном Хусерловом учењу) од природног става и његовог преимућства у виду непосредне усмерености на „врховну стварност“ свакодневног живота.

Шицов појам природног става, који је на овај начин готово потпуно ослобођен од значења које у њега уноси појам феноменолошког става (будући да се феноменолошки став не сматра његовом супротношћу), појам је који може бити испуњен потпуно другачијом теоријском конотацијом. Као такав, Шицов природни став као специфичан однос према свету свакодневног живота може подједнако бити начин на који Дјуи илуструје свакодневно животно искуство у Логищ̧и, теорији истраживања (Дјуи 1962: 111-127), као што може бити и Хусерлов природни став - потребно је само „ставити у заграде“ Дјуијев натурализам на исти начин на који се Шиц овде ограђује од карактеристика Хусерловог феноменолошког епохеа. На овај начин се теорија аустријског филозофа у извесном смислу либерализује у односу на феноменолошко наслеђе - што се не мора сматрати проблемом, посебно уколико се тиме за интерпретатора Шицовог учења отвара могућност директног поређења његове теорије са другим усмерењима, попут већ сугерисаног Дјуијевог или Џемсовог учења. Међутим, изгледа да се у оваквом Шицовом поступању могу уочити и неки конкретнији проблеми, непосредно повезани са целовитошћу саме концепције овог аутора. Да бисмо их илустровали, послужићемо се једним Шицовим увидом из текста о вишеструким стварностима. 
Приликом дубљег разматрања алтернативне стварности фантазије, аустријски теоретичар наводи опсежан Хусерлов цитат о овој проблематици (Шиц 2012: 296). У њему, родоначелник феноменологије објашњава како се фантазирањем не отвара само један нови свет који нуди нове, другачије садржаје од оних које доживљавамо у домену свакодневног живота, него се заузимањем овог става, а затим и повратком свести у свет јаве, конституише у тој свести и сам природни став и њему одговарајући свет. ,'Са природним ставом на самом почетку (пре размишљања) нема предиката 'стварно' и нема категорије 'стварност'. Само ако фантазирамо и пређемо са става живљења у фантазији на дате стварности (....), онда добијамо, с једне стране појмове фикције (...), а с друге појмове (...) стварности“ (Шиц 2012: 296). Иако Шиц из овог цитата изводи закључке који се тичу самог света фантазије, Хусерлово истицање чињенице да свет стварности и природни став који му одговара бивају расветљени за једну свест тек када се сагледају „од споља“ нагони нас да се запитамо да ли се ова напомена може применити и на Шицово сопствено разумевање природног става и света свакодневног живота. Наиме, ако нема одређене алтернативе природном ставу у виду феноменолошког става, којим се ставља у заграде постојање света искуства, да ли се и Шицова теорија која се тиче природног става такође налази у ситуацији у којој „нема предиката 'стварно' и нема категорије 'стварности'“?

Разуме се, Шицово учење се не налази у теоријском контексту унутар кога би требало бранити усмерење ка анализи живота свести и правилности у њеном поступању од приговора о постојању спољашњег света које би могао заступати скепти. Додуше, сам Хусерл има у виду и овакве проблеме на почетку Картезијанских медитација, управо у контексту заузимања феноменолошког става (Husserl 1975: 58). Међутим, Шиц се приближава овој проблематици када подухват одговарајућег тематизовања проблема стварности свакодневног живота у већ поменутом тексту „Феноменологија и друштвене науке“ придаје феноменологији као један од њених основних задатака (Шиц 2012: 171, 173-174). Аустријски филозоф на том месту говори о томе да се задатак феноменолошке редукције не састоји у томе да „оспори стварно постојање света живота“, већ се проблем ове стварности „мора објаснити“ (Шиц 2012: 173). Ипак, није сасвим јасно на који начин ће се у Шицовој концепцији једна дисциплина, моделована по узору на феноменологију, ухватити у коштац са таквим „објашњењем“ стварности света, уколико је свест у домену научне контемплације зароњена у претпоставку о постојању света искуства као „врховне стварности“. ${ }^{2}$ Тако се

\footnotetext{
${ }^{2}$ У коришћеном преводу првог тома Шицових сабраних дела, на наведеном месту се може наћи једно проблематично преводилачко решење. Наиме, након већ цитиране Шицове реченице у којој се каже да „за трансценденталну феноменологију не постоји сумња да свет постоји и да се манифестује у континуитету хармоничних искустава као универзум“ налазимо реченицу која гласи: „Међутим, та сумња се мора објаснити (...)“ (Шиц 2012: 173). У оригиналном енглеском тексту сабраних дела, уместо одређеног енглеског еквивалента за реч „сумња“, на овом месту налазимо реч „,indubitability“, која именује нешто сасвим супротно сумњи - несумњивост (Schutz 1971: 122). Иако би се из контекста могло закључити да Шиц тиме указује на нужност адекватног
} 
питање о томе где потражити феноменолошки став у концепцији аустријског теоретичара претвара још једном у питање о томе које је место и улога феноменолошке филозофије у Шицовом учењу, а посебно у његовој класификацији вишеструких стварности и њима одговарајућих ставова. Извесно решење за овај проблем могло би се потражити одређеним раздвајањем феноменологије од домена научне контемплације - али сам Шиц ни у тексту о вишеструким стварностима, као ни у другим текстовима обједињеним у првом тому сабраних дела, то не чини, нити сугерише начин на који би то требало спровести. О овоме ће бити више речи у наредним поглављима овог рада. Пре него што се вратимо овој проблематици, размотримо укратко и начин на који је проблематика Хусерловог трансценденталног става пронашла своје место и у контексту Шицовог говора о проблему интерсубјективности.

Још један начин на који се Шиц односи према феноменолошком наслеђу сугерише нам да се аустријски филозоф колеба када је реч о релевантности те традиције у решавању проблема које он отвара у различитим текстовима првог тома сабраних дела. Коментаришући Шелерове и Хусерлове ставове о интерсубјективности и различите начине на које се овом проблему може приступити унутар одређених теоријских концепција, Шиц исказује сумњу у то да проблем постојања алтер ега треба решавати на трансценденталном нивоу (Шиц 2012: 221; Barber 2020). Интересантно је да се ова сугестија аустријског теоретичара, без обзира на то што је директно усмерена на проблем интерсубјективности, може искористити и за општије сагледавање Шицовог односа према Хусерловој трансценденталној филозофији. Иако нећемо улазити у разматрање начина на који је родоначелник феноменологије покушао да реши проблеме постојања друге свести, важно је напоменути да Хусерл свакако тежи управо трансценденталистичком решењу проблема интерсубјективности. Такво решење би у његовој концепцији требало пронаћи у самој трансценденталној апаратури свести која опажа друго биће (Husserl 1975: 37-38). Шиц указује на одређене слабости предложеног Хусерловог решења, указујући, између осталог, и на то да је интерсубјективност неизбежно дата свести и пре оваквог подухвата. Ово је аустријски филозоф истакао не само у познатим речима да је то случај самом чињеницом да нас „на овај свет доносе и подижу мајке” (Шиц 2012: 222), него и тиме што смо окружени предметима који су испуњени садржајем који је у њих доспео захваљујући (интерсубјективној) култури у којој су настали (Шиц 2012: 174, 184, 186).

Међутим, иако одбацује трансценденталистичко усмерење, Шиц ипак користи и извесне теоријске домете до којих је аутор Картезијанских медитација дошао управо у решавању проблема интерсубјективности. То је посебно случај

објашњења подухвата који на себе преузима феноменолог, термин „сумња“ у овом контексту ипак може наводити читаоца на погрешан траг, сугеришући да је потребно објаснити разлоге због којих феноменолог спроводи методску сумњу у виду феноменолошког епохеа. Међутим, на то Шиц не циља у овом делу текста, већ сматра да треба објаснити механизме на основу којих се феноменолог, након спроведених анализа на трансценденталном нивоу, враћа у домен света свакодневног живота и примењује на њега сазнања добијена на том нивоу. 
када је реч о Хусерловом појму апрезентације, којим родоначелник феноменологије именује специфично поступање свести уз помоћ кога се једном искуству могу придодати карактеристике другог искуства, које субјект не доживљава непосредно, али ка коме прво искуство буди одређене асоцијације (Шиц 2012: 175-176; Husserl 1975: 127-129). Као што “гледана предња страна једне ствари увијек и нужно апрезентира задњу страну ствари” при посматрању једног спољашњег предмета (Husserl 1975: 127), тако се тело алтер ега "апрезентује" као тело (а не неки објекат друге врсте). То једна свест може спровести захваљујући томе што она има искуство свог тела, које на овај начин примењује на предмет свог искуства који препознаје као друго тело (Шиц 2012: 175-176, 199-200, 219-220. Husserl 1975: 128, 131-132, 133-134). Овако започиње препознавање другог субјекта као друге свести у Хусерловом учењу, од кога се Шиц ограђује. Међутим, иако зазире од решавања проблема интерсубјективности на трансценденталном нивоу, Шиц истовремено ипак не уочава да и сам предлаже теоријска решења до којих се долази управо преко проблематичног истраживања дубина трансценденталне апаратуре. То је уочљиво у последњим пасусима текста о Шелеровом појму интерсубјективности, у којима Шиц, уместо закључка, сугерише да проблем интерсубјективности даље треба развијати управо применом Хусерлове апрезентације у случају тела алтер ега (иако овде не употребљава термин “апрезентација”) (Шиц 2012: 232-233). Следствено томе, Шицова примена теоријских домета трансценденталне феноменологије није ограничена само на његову примену појма епохеа, него тежи и ка примени специфичнијих, апстрактнијих решења попут „апрезентативног упаривања” (Шиц 2012: 176, 220). Не циљајући директно на специфичан теоријски мотив апрезентације, управо ће Нејтенсон заоштрити проблем који се јавља на овом нивоу Шицовог одношења према Хусерловом феноменолошком наслеђу. Већ смо поменули да се дисквалификација трансценденталистичког решења у Шицовом учењу спроводи указивањем на то да се субјект заправо и рађа и развија у контексту који је нужно интерсубјективан. Међутим, Нејтенсон ће сугерисати да би једно трансценденталистичко решење проблема интерсубјективности заиста показало да свест може доживети објекат свог искуства као другу свест (а не као пуки предмет) (Natanson 1970: 115-116). Такво решење би указало на то да је могућност искуства алтер ега један аспект саме структуре свести субјекта у свакодневном животу. Другим речима, можда је трансценденталистичко решење потребно и у једној „феноменологији природног става”, а не само у Хусерловој трансценденталној феноменологији. У раду ћемо се вратити још једном на овај Нејтенсонов став, сагледавајући га у контексту других приговора које он упућује изостанку отвореног дискурса о феноменолошком ставу у Шицовом учењу. Пре излагања Нејтенсонове критике Шицовог учења, потребно је осврнути се на начин на који у учењу аустријског теоретичара долази до занемаривања феноменолошког става приликом разматрања специфичног теоријског става који према свету заузима научник. 


\section{Научна контемплација и феноменолошки став}

Иако у тексту „Феноменологија и друштвене науке” истиче, а затим и проблематизује велике амбиције феноменологије као „строге науке”, Шиц у њему не одбацује овакво Хусерлово стремљење, верујући да постоји „допринос који феноменологија може да има за конкретне методолошке проблеме" (Шиц 2012: 170). Аустријски теоретичар велику улогу придаје управо сазнањима до којих феноменолог долази на трансценденталном нивоу: „трансцендентална феноменологија не прихвата ништа као очигледно само по себи, она превазилази сав наивни позитивизам и може да очекује да ће постати истинска наука ума" (Шиц 2012: 171). За разлику од текстова о вишеструкој стварности и неким основним појмовима феноменологије, овај текст је објављен нешто раније (1940. године), па се интензивнија Шицова верност изворном облику феноменолошке филозофије може оправдати и том чињеницом.

Посебно је интересантно да у оквиру четвртог потенцијалног приговора великим амбицијама феноменологије Шиц помиње и мишљење према коме би психологија могла представљати адекватније теоријско тло за проучавање различитих проблема домена културе, и то психологија која је усмерена ка свакодневном животу (Шиц 2012: 173). Начин на који Шиц одговара на овај приговор може представљати интересантан увид уколико не губимо из вида претходно поменуте ставове о научној контемплацији из списа о вишеструким стварностима. Наиме, Шиц у одговору на поменути приговор заиста указује на извесне разлике које постоје између научног приступа проблемима културе и феноменолошког става који одговара хусерловској филозофији. Између осталог, он каже да је заједничка карактеристика различитих „наука културе” то што остају у домену „прозаичне интерсубјективности”, односно узимају здраво за готово друштвену стварност која представља предмет њихове теоријске обраде (Шиц 2012: 183). Као такви, феноменолошки увиди који припадају трансценденталној сфери ,једва да улазе у видно поље наука културе” (Шиц 2012: 183). Изложени став потпуно је у складу са начином на који је Шиц представио научну делатност у спису о вишеструким стварностима, у коме истиче да став научне контемплације мора бити утемељен на природном ставу и веровању у објективно постојање света искуства (па тиме и објективно постојање алтер ега, без кога нема предмета друштвених наука). Ипак, изгледа да се то не односи на претходно поменуту психологију (која је у тексту управо и поменута због њене повезаности са свакодневним животом). Аустријски филозоф истиче да психологија „мора постати свесна чињенице да се она не бави емпиријским чињеницама” и да „мора да буде наука суштине, истражујући последице оних трансценденталних конститутивних феномена који су повезани са природним ставом" (Шиц 2012: 183). Иако је не удаљава у потпуности од природног става, очекујући од ње да ставове добијене на нивоу трансценденталне сфере примени на проблеме који искрсавају у природном ставу, уочљиво је да Шиц од ње истовремено захтева да и сама буде способна да говори језиком 
трансценденталне сфере. У наставку пасуса Шиц поткрепљује ово мишљење Хусерловим повезивањем феноменолошког пројекта са "правом психологијом интенционалности” (Шиц 2012: 183). Међутим, овакав став ипак изазива извесне проблеме у Шицовом учењу, уколико сматрамо да се ставови које је аустријски теоретичар изложио у поменутом раном тексту могу с правом повезати са његовим учењем у тексту о вишеструким стварностима. Наиме, уколико се, из перспективе текста о вишеструким стварностима, теоријски став психолога сматра „ставом научне контемплације”, онда се његова делатност ипак мора директније усмерити на домен природног става, који научни став подразумева, па се од трансценденталистичких тенденција мора одустати. Са друге стране, уколико се ипак жели задржати поменуто Шицово мишљење о задатку психологије, онда би се његово разумевање става научне контемплације морало допунити тако да допусти и специфичан Хусерлов феноменолошки став. Тако би специфичан став феноменологије омогућио психологији да узме у обзир поменуте „трансценденталне конститутивне феномене”, а у крајњој инстанци и саму „науку суштине” о којој је реч у наведеној Шицовој тврдњи о психологији. Међутим, у том случају би Шиц морао одустати од мишљења према коме се став научника увек одвија у домену природног става. У било којој од поменутих интерпретација одређени аспекти саме Шицове теорије би се морали „ставити у заграде”.

На крају пасуса у коме је реч о односу између феноменологије и других теоријских дисциплина које су ближе повезане са природним ставом, Шиц још једном, као и у пар других текстова (Шиц 2012: 155, 183, 201) истиче потпуну компатибилност између теза до којих феноменолог долази на нивоу трансценденталне сфере и увида до којих је могуће доћи у природном ставу. Као ни у другим текстовима, ни у овом случају аустријски филозоф не разрађује на одговарајући начин поменуту тезу о компатибилности природног и феноменолошког става. Међутим, уколико у Шицовом учењу феноменолошки став нема одговарајућу позицију у систему алтернативних стварности које отвара свет науке, онда није сасвим јасно како у његовој концепцији “спустити” на домен природног става хусерловске ставове о структури свести и њеној трансценденталној апаратури. Будући да није добила одговарајуће позиционирање у домену става научне контемплације - а и не може га добити уколико се инсистира на томе да се научна контемплација обавља унутар природног става - онда би се могла довести у питање научна релевантност феноменологије.

Шиц завршава текст о односу феноменологије и друштвених наука речима да ће „таква наука у Хусерловим испитивањима у области трансценденталне феноменологије наћи нешто више од идеје водиље” (Шиц 2012: 189). Ипак, пет година након овог става, сам Шиц у тексту о вишеструким стварностима једва да и помиње феноменолошки став, уз помоћ кога Хусерл долази до увида о трансценденталној структури свести субјекта, иако наставља да се позива на теоријска решења феноменологије. Међутим, изгледа да је сам аутор књиге о проблему друштвене стварности највише утицао на друштвене науке управо сопственим увидима (па чак и сопственим терминолошким решењима), а не 
толико преношењем Хусерловог феноменолошког наслеђа у домен друштвене науке (уп. Berger, Luckmann 1992: 39-43; Nasu 1999: 72).

У знатно касније написаном тексту „Хусерлов значај за друштвене науке” (1959) Шиц на самом почетку критикује одређене ауторе који су покушали да примене „методу еидетичке редукције” на друштвене науке (Шиц 2012: 191192). Ова метода је директан продукт Хусерлове феноменологије, до кога овај мислилац долази управо захваљујући одношењу према садржајима добијеним у феноменолошком ставу (Husserl 1983: хx). Проблем са оваквом применом феноменологије лежи у томе што, према Шицу, она води ове ауторе до „формулисања одређених аподиктичких и наводно априористичких тврдњи које су довеле дискредитовању феноменологије” (Шиц 2012: 192). Међутим, независно од начина на који је ово случај у теоријама аутора које аустријски филозоф овде наводи и без намере да доводимо у питање овакву Шицову критику априористичких теоријских усмерења, испитајмо шта он у овом тексту сматра одговарајућом применом феноменолошког наслеђа у домену друштвених наука. У другом делу поменутог текста, Шиц износи седам проблема друштвених наука који могу бити разматрани из перспективе феноменолошког наслеђа (Шиц 2012: 197-201). Ове проблеме - који највећим делом одговарају уобичајеним Шицовим преокупацијама које се тичу начина на који се субјект односи према делању у свакодневном животу и проблема интерсубјективности - аустријски филозоф излаже користећи Хусерлову филозофску терминологију и имплицитно указујући на нека сопствена теоријска решења. У разради тих проблема, ни на једном месту не налазимо Шицов упут који би се тицао тога како избећи априористички тон у друштвеној науци уколико користимо домете Хусерлове феноменологије, па чак и у случају када једноставно примењујемо Хусерлову терминологију, која заиста има априористичку конотацију. Хусерл је прилично отворен када је реч о априористичким претензијама сопствене филозофије. Он управо у (кантовском) истицању могућности сазнања а приори у трансценденталном ставу он види предности феноменолошког филозофирања и шансу да управо феноменологија буде ,универзална знаност” (Husserl 1975: 21, 36, 39-41, 67-70).

Текст из 1959. године Шиц закључује тврдњом ,да ће емпиријске друштвене науке наћи своју праву основу не у трансценденталној феноменологији, већ у конститутивној феноменологији природног става” (Шиц 2012: 192). Аутор књиге о проблему друштвене стварности овде директно оповргава сопствену тврдњу из текста из 1940. године у којој указује на то да ће друштвене науке „у области трансценденталне феноменологије наћи нешто више од идеје водиље”, што директно сведочи о Шицовом колебању на које су указали аутори у литератури о аустријском филозофу (Шиц 2012: 189). У поменутом закључку текста о Хусерловом значају за друштвене науке наилазимо још само на његово стандардно подсећање читаоца да су „анализе изведене у редукованој сфери”, након стављања у заграде објективног постојања спољашњег света, „валидне и за домен природног става" (Шиц 2012: 201). 


\section{Нејтенсонова критика Шицовог занемаривања феноменолошког става}

Иако проблем улоге феноменолошког става у Шицовој теорији није пуно разматран у литератури у учењу аустријског теоретичара, посебно је занимљиво што увид о том проблему налазимо управо у једном тексту Мориса Нејтенсона, уредника првог тома Шицових сабраних дела који обрађујемо у овом раду. У тексту о начину на који су појам друштвене стварности и друштвене науке представљени у раној Шицовој књизи Феноменологија друштвеног света, Нејтенсон указује и на извесна ограничења теоријске концепције успостављене у овој књизи (Natanson 1970: 114-119). Као што се основни појмови Шицове филозофије - “зато-што” и “да-би” мотиви, као и “однос лицем-у-лице”, на које Нејтенсон (1970: 108-110) указује у овом тексту - поклапају са учењем које Шиц (2012: 118-120, 275-279) излаже у првој књизи сабраних дела, то је случај и са ограничењима које уредник поменутог првог тома у том тексту истиче. Управо се први проблем који он уочава у Феноменологији друштвеног света тиче Шицовог односа према феноменолошком ставу. Наглашавајући да се анализа унутрашњег времена свести у раној Шицовој књизи одвија након спроведене феноменолошке редукције, Нејтенсон истиче да се Шицово спровођење те Хусерлове методе ограничава на овај изоловани случај, а да не постоји разлог за такво поступање аустријског филозофа (Natanson 1970: $114,115)$. Штавише, посебно је интересантно да уредник првог тома Шицових сабраних дела на овом месту истиче да је нејасно зашто је Шиц занемарио перспективу феноменолошког става у случају анализе проблема интерсубјективности. Разуме се, Нејтенсон у овом делу текста и сам сматра да је занемаривање феноменолошког става у случају овог проблема највероватније директно мотивисано Шицовом критиком Хусерловог покушаја да реши овај проблем у Картезијанским медитацијама (Natanson 1970: 116-117). Ово је у потпуности уочљиво и у текстовима обједињеним у првом тому Шицових сабраних дела, будући да се у готово сваком тексту говори о овом Хусерловом проблематичном решењу. Међутим, Нејтенсон у овом тексту одлази и корак даље приликом указивања на Шицово занемаривање феноменолошког става у поменутој раној књизи. Он се не задовољава једноставним проглашавањем овог аспекта Шицовог учења главном тачком његовог разилажења од Хусерловог учења, будући да не сматра да би анализа проблема интерсубјективности из перспективе трансценденталног, феноменолошког става представљала тек својеврсну допуну Шицовог учења о алтер егу. Напротив, Нејтенсон сматра да у оквиру Шицове феноменологије природног става интерсубјективност није теоријски проблем у правом смислу те речи, већ „чињеница живота” (Natanson 1970: 115), а да тек са тачке гледишта трансценденталне филозофије заправо представља изазов (па је из те перспективе представљао тешкоћу и у Хусерловом случају). Потребно је унутар говора о структури свесног живота субјекта показати како је могућ алтер его - насупрот томе, у природном ставу, алтер его је већ ту. Не задржавајући се само на проблему интерсубјективности, уредник првог тома Шицових сабраних дела показује да на овај начин аустријски филозоф треба 
објаснити и друге тезе у свом учењу. То треба учинити и у случају његовог говора о систему релевантности и фундаменталној стрепњи као о оној темељној карактеристици човековог живота која одређује шта треба сматрати релевантним унутар искуственог живота (Natanson 1970: 118). Притом, Нејтенсон непосредно тврди да стандардно Шицово “решење” у оваквим случајевима - указивање на то да се анализе спроведене у феноменолошком ставу могу директно применити на одговарајуће аспекте природног става - није довољно (Natanson 1970: 114-115). Он проблематизује ову једноставну претпоставку Шицовог учења, усмеравајући критику концепције аустријског филозофа ка проблемима који се не тичу конкретних решења које нуди његова теорија, већ у правцу извесних методолошких неадекватности у овом учењу. Нејтенсон на овом месту у тексту на занимљив начин окреће Шицову концепцију против њега самог. Шицов следбеник указује на то да се тврдња о усагласивости садржаја до кога феноменолог долази у трансценденталном ставу са искуствима у природном ставу може бранити „само из перспективе преимућстава феноменолошке редукције” (Natanson 1970: 115). Након што пређе целокупну путању од стављања у заграде става о веровању у објективно постојање спољашњег света до „нововрсног, трансценденталног искуства”, феноменолог се може безбедно вратити домену природног става. Тада, наглашава Нејтенсон (1970: 115), он може безбедно и ограничити поље свог интересовања, што је намера коју Шиц испољава и у текстовима обједињеним у првом тому сабраних дела.

Овим се на још један начин потврђује међузависност природног и феноменолошког става на коју смо у раду указали. Нејтенсоновом критиком се успоставља одређени континутитет између ранијих и каснијих Шицових текстова када је реч о његовом амбивалентном односу према Хусерловом феноменолошком ставу. Ипак, интересантно је да уредник првог тома Шицових сабраних дела у поменутом тексту изложену критику учења аустријског теоретичара не сматра посебно проблематичном. Он не доводи у питање његово феноменолошко усмерење, већ феноменолошки карактер његовог учења додатно истиче на крају текста о друштвеној реалности и друштвеној науци у Шицовом учењу (Natanson 1970: 120). Како онда протумачити упадљиви изостанак Шицовог говора о трансценденталном ставу у различитим деловима његовог теоријског опуса? Размотримо у наставку рада да ли би се у оваквом Шицовом поступању могле наћи основе за тврдњу о стремљењима Хусерловог следбеника ка другачијем теоријском опредељењу.

\section{Шицова феноменологија природног става и прагматистичко учење}

Шицово удаљавање од изворног Хусерловог феноменолошког учења и занемаривање трансценденталне перспективе коју отвара феноменолошки став могло би се тумачити уз помоћ разматрања могућности Шицовог приближавања једној другачијој теоријској традицији - прагматистичкој филозофији. Ова могућност пре свега лежи у већ поменутој чињеници да у текстовима обје- 
дињеним у првом тому сабраних дела Шиц често указује на различите теоријске ставове Вилијама Џемса и Џона Дјуија. Такође, оваква интерпретација би се могла поткрепити и тиме што се управо у основним ставовима прагматизма може наћи окретање анализи искуства свакодневног живота, а ово је, као што је у раду већ поменуто, посебно уочљиво у Дјуијевој филозофији у Логищи, теорији истраживања (коју Шиц има у виду и реферише на њу у првом тому сабраних дела) (Шиц 2012: 49, 388, 414). Поред тога, сам је Дјуи врло скептичан када је реч о трагању за „,априорним категоријама” и „структуром 'мишљења'“ (Дјуи 1962: 527-529). Са друге стране, и у Џемсовој филозофији се даје велика важност перспективи свакодневног живота, што је евидентно чак и у његовој несрећној “cash-value” метафори која је учинила да прагматизам избије на лош глас у америчким филозофским круговима (Џемс 1940: 38. Cotkin 1985: 37). Додуше, Џемсова прагматистичка филозофија је у Прагматизму била у извесном смислу попустљивија према трансценденталистичким филозофским решењима (што очигледно допушта његово коришћење Папинијеве [Giovanni Papini] метафоре ходника који води „у безброј одаја”) (Џемс 1940: 38-39). Међутим, радикални емпиризам Џемсовог учења у његовом познатом тексту „Да ли свест 'постоји'“ би одбацио основно феноменолошко усмерење у виду анализе живота свести (Џемс 1940: 175-179).

Ипак, да ли би теоријска клима прагматизма одговарала Шицовим теоријским намерама? Наиме, иако се одређени аспекти разноврсног учења двојице поменутих аутора често помињу у текстовима првог тома Шицових сабраних дела, сам прагматизам се врло ретко помиње - а тада се о њему говори врло негативно. Управо у једној фусноти у тексту о вишеструким стварностима, изгледа да Шиц прагматизму негира сваку теоријску адекватност. Наглашавајући да се прагматизам не бави „конституисањем свесног живота“, што се може сматрати очекиваном критиком коју упућује један следбеник феноменологије, Шиц дискредитује прагматизам сматрајући га здраворазумским излагањем поступања субјекта у свакодневном животу, ,а не и филозофијом „која истражује претпоставке такве ситуације“ (Шиц 2012: 270). Другим речима, уроњеност прагматизма у домен свакодневног живота аустријски филозоф тумачи као његову капитулацију пред теоријском рефлексијом о свакодневном животу. Међутим, изгледа да се Шицова сажета критика прагматистичког теоријског усмерења може вратити и њему самом. Уколико се од теоријског третмана одређеног аспекта свакодневног живота очекује рефлексивност која ће се тицати „конституисања свесног живота” и његових “претпоставки”, изгледа да је самом Шицу у анализи различитих феномена унутар природног става потребна рефлексија која ће трансцендирати оквире природног става. Такво трансцендирање омогућава управо феноменолошки став, који Шиц у свом учењу занемарује, мада користи све плодове Хусерловог теоретисања спроведеног након стављања у заграде веровања у објективно постојање света унутар искуства свакодневног живота.

Независно од наведеног проблема, Шицово удаљавање од прагматистичког наслеђа може се објаснити и из перспективе неспојивости његовог учења са 
неким другим аспектима Џемсове и Дјуијеве теорије. Ово је посебно уочљиво у случају Шицовог односа према Дјуијевој филозофији. Аустријски филозоф у пар наврата у текстовима првог тома сабраних дела, директно или индиректно, сугерише да је његово феноменолошко усмерење неспојиво са одређеним облицима натуралистичког учења (Шиц 2012: 100-101, 182). Међутим, управо се Дјуијев прагматизам у Логищи, теорији истраживања конституише на темељу натуралистичких претпоставки. У овој књизи Дјуи најпре говори о интеракцији човека као организма и његове околине, а на темељу ове биолошки условљене интеракције развија и тезу о континуитету између различитих облика искуственог живота човека - његових свакодневних животних активности, али и научне делатности (Дјуи 1962: 74-75, 79-81). Указивање на биолошку основу човековог искуства у Дјуијевој филозофији игра ону улогу коју у Шицовој теоријској концепцији имају основни ставови феноменологије - Дјуију није потребан говор о структури свесног живота субјекта, будући да су обрасци свести биолошки условљени. Са друге стране, феноменологу, па и Шицу који из ове перспективе критикује натуралистичко становиште, биолошки условљено понашање не пружа одговарајуће објашњење начина на који свест конституише свет око себе, већ трага за дубљим утемељењем оваквог поступања у трансценденталној апаратури субјекта искуства. Дјуи би овакво филозофско усмерење вероватно одбацио као интелектуалистичко теоријско решење које инсистира на свесном животу као духовној страни човекове личности, умањујући важност телесног живота и одвајајући на вештачки начин човека од осталих живих бића (Дјуи 1962: 76-77, 79-81).

Изгледа да је у оваквом етикетирању натурализма Шиц мотивисан сличним разлозима због којих би могао дискредитовати и Џемсову филозофију. Наиме, Шиц на више места у овој књизи критикује бихевиористичко теоријско усмерење (Шиц 2012: 101-102, 248-249, 265-266, 275). Ово је такође сасвим очекивано од феноменолошки усмереног мислиоца, будући да такво теоријско опредељење одбацује саму основу на којој је феноменологија подигнута - тумачење поступања човека као манифестације његовог свесног живота (Hauser 2020). Интересантно је да се оваква Шицова критика може проширити тако да се њоме објасни и начин на који је његова концепција теоријски удаљена и од Џемсовог учења, које се, према одређеним интерпретацијама поменутог текста о проблему постојања свести, сматра претечом бихевиоризма (Hauser 2020; Wozniak 1993: хxхі-хxхіi). Као и претходно поменути Дјуијев натурализам, тако и бихевиоризам коме се Џемсово учење приближава, о понашању човека закључују на основу манифестација његовог понашања у човековој околини као пољу његовог делања. Међутим, Шиц као феноменолог не би сматрао да се оваквим закључивањем на основу манифестација понашања субјекта долази до одговарајућег темеља на основу кога теоретичар заиста објашњава то понашање. Он би заступао тезу да се објашњење постиже тек теоријском анализом структуре свесног живота, колико год да се поступања субјекта искуства могу објаснити посматрањем његовог понашања. Иако би оваквом критиком Шиц још једном могао потврдити своју приврженост феноменолошком наслеђу, он 
сам у текстовима првог тома сабраних дела не успоставља методологију уз помоћ које би се теоретичар удаљио од ,здраворазумског излагања поступања субјекта" и приближио перспективи са које је структура свесног живота сагледива. Управо овакву методологију обезбеђује Хусерлов прелаз са природног на феноменолошки став.

\section{Потрага за решењем: Шицово учење и Лукманова подела на феноменологију и социологију}

Можда је управо услед уочавања да се феноменологија и њен априористички тон не могу лако ускладити са емпиријским стремљењима друштвених наука Шиц избегао да успостави одговарајући однос између феноменологије као теоријске делатности и става научне контемплације о коме говори у тексту о вишеструким стварностима. Међутим, док овакву врсту отвореног одвајања ових теоријских делатности не налазимо код самог Шица, изгледа да су њу спровели управо они следбеници аустријског филозофа који су његово учење применили у контексту друштвене науке. Према Томасу Еберлију (Thomas $S$. Eberle), управо је Лукман (Thomas Luckmann) на Шицовом трагу отворено упоредио феноменолошку филозофију и социологију (Eberle 2012: 135, 138). Феноменологија у његовој концепцији јесте филозофско учење које може представљати одговарајућу основу за социологију (па се Шицова феноменологија природног става овде и назива “прото-социологијом”), али се према предмету теоријске обраде, као и према методама које примењује, јасно разликује од друштвених наука (Eberle 2012: 135, 138). Еберли наводи да Лукман феноменологији придаје еголошки приступ, методу која се заснива на увидима до којих свест долази рефлексијом о поступању субјекта искуства, а тематика којој се она окреће тиче се „феномена субјективне свести” (Eberle 2012: 138). Поред оваквог теоријског усмерења, феноменологији се овде придаје и циљ у виду истраживања ,универзалних структура оријентације субјекта у свету живота" (Eberle 2012: 138).

Овакво одређење директно упућује на Шицову феноменологију, док се не може у потпуности применити на Хусерлову филозофију у Картезијанским медитацијама. Она се усмерава на истраживање трансценденталне апаратуре субјекта искуства независно од њене непосредне примене на свет живота, иако и сам родоначелник феноменологије истиче да се ставови до којих долази након извршене трансценденталне редукције могу применити и на искуства субјекта у природном стању. Са друге стране, иако је Хусерлово касније истицање важности окретања свету живота у филозофском и научном приступу стварности у Кризи европских наука мотивисано другачијим циљевима од истраживања структуре свести субјекта, његово се рано феноменолошко учење заиста може ускладити са његовим теоријским преокупацијама у књизи о стању науке у првој половини 20. века. Сам родоначелник феноменологије у једном делу касније написане књиге заговара овакво повезивање (Хусерл 1991: 120- 
129. Luckmann 1978: 179-180). Међутим, имајући у виду разлике између теоријских усмерења Хусерлове феноменологије у Картезијанским медитацијама и теоријских тенденција Кризе европских наука, остаје отворено питање да ли је ова компатибилност у потпуности изводива. Хусерл у касније написаној књизи указује на основне мотиве свог феноменолошког учења тек након што о свету живота говори из перспективе критике становишта да се свет као предмет научног истраживања може просто изједначити са светом датим искуству свакодневног живота (Хусерл 1991: 27, 47-49). Другим речима, чини се да Хусерлов појам света живота у Кризи европских наука претпоставља много више нијанси значења него што то може пружити појам света који родоначелник феноменологије има у виду у теоријском контексту Картезијанских медитащија. Ипак, изгледа да се у Шицовој феноменологији не може наћи дилема овакве врсте. Он у једнакој мери говори и о природном ставу и о свету живота, без обзира на то што први термин превасходно упућује на достигнућа Хусерлове анализе свести, док други упућује на афирмацију проучавања искуства света свакодневног живота независно од начина на који се свет разуме у природним наукама (Хусерл 1991: 110-114).

Иако Лукман поделу на феноменологију и социологију креира са Шицовог теоријског усмерења, ипак се можемо запитати да ли изложени опис феноменолошког учења одговара и теоријским намерама аустријског филозофа у текстовима првог тома његових сабраних дела. Најпре би се могао довести у питање став о томе да је Шицова феноменологија природног става заправо еголошка. Управо се у чињеници да се Шиц клони хусерловског трансценденталистичког приступа, према коме се до увида о начину на који се одвија свесни живот субјекта долази након стављања у заграде веровања у објективно постојање света, може тражити и основ за другачије методолошко усмерење овог аутора. Док је Хусерлова метода у Картезијанским медитаџијама заиста еголошка, будући да се до филозофских закључака долази тек када се свест редукује на „его чистих cogitationes” (Husserl 1975: 46), Шиц преузима Хусерлове увиде и реконтекстуализује их. Он ставове родоначелника феноменологије примењује унутар концепције која се не ограничава на поступање свести мимо веровања у објективно постојање света, већ као предмет теоријске обраде непосредно узима начин на који свест поступа у природном ставу.

Без обзира на поменуте проблеме, Лукманова подела на филозофски, односно прото-социолошки приступ и социолошки, то јест, друштвено-научни приступ феноменима ипак се може применити у решавању проблема неодређеног статуса феноменонолошког става у Шицовом учењу о вишеструким стварностима. Према Еберлију, Лукман недвосмислено наглашава да се прото-социолошка теорија не може сматрати “научном”, иако увиди социологије као науке морају бити ускладиви са феноменолошким ставовима до којих се долази теоријском рефлексијом, а не емпиријским истраживањем (Eberle 2012: 138; уп. и Berger, Luckmann 1992: 37-38). Претходно наведено Лукманово одређење феноменологије може се у извесном смислу проширити, тако да не обухвата само шицовско усмерење ка „универзалној структури оријентације субјекта у свету 
живота". Оно се може приближити ширим Хусерловим теоријским намерама, при чему би се феноменолошки став могао одвојити од става научне контемплације о коме Шиц говори у тексту о вишеструким стварностима и разматрати се као „омеђена област значења” посебне врсте. Наиме, начин на који Лукман говори о односу између социологије као науке и Шицове феноменолошке филозофије на коју следбеник аустријског теоретичара циља говором о „оријентацији субјекта у свету живота”, може се применити и на проблематичан однос Шицовог учења и хусерловског филозофског наслеђа. Као што „социолошки концепти и теорије морају реферисати на основне структуре” свести до којих долази феноменологија (Eberle 2012: 138), тако и Шицово учење, отворено ка различитим утицајима, па и емпиријским научним увидима, мора остати “верно” структурама свести до којих Хусерлова филозофија долази еголошким приступом. Овакво решење у извесном смислу подсећа на један већ поменути теоријски захтев - Хусерлово истицање компатибилности учења из Кризе европских наука, које се усмерава ка „свету живота”, и његове ране феноменологије. У случају Шицовог учења, које и само гравитира управо ка терминологији коју налазимо у учењу касног Хусерла, може се успоставити слична тврдња о повезаности са изворним обликом феноменологије. На овај начин, Лукманово одређење улоге феноменологије и социологије, које садржи већ илустроване проблеме када је реч о прешироком разумевању феноменологије, могло би се проширити тако што би предложена подела сада постала тројака. Хусерлова рана феноменологија тако би се нашла у основи, а њена би метода заиста била еголошка и рефлексивна (уп. Eberle 2012: 137-138). Шицова изведена „конститутивна феноменологија природног става" (Шиц 2012: 183, 189, 200-201) нашла би се између хусерловског трансцендентално-феноменолошког приступа и социологије. Њена метода се не би могла сматрати ни еголошком, ни стриктно научном, већ у извесном смислу еклектичном - допуњеном теоријским увидима прагматизма, психологије, социологије и економије, али и стремљењима касније Хусерлове феноменологије (уп. Натансон 2012a, 42). На крају овог низа би се нашла Лукманова феноменолошки инспирисана социологија, која се пре свега ослања на изведене Шицове увиде, али се, индиректно, по Лукмановој сопственој сугестији, може повезати и са базом у виду Хусерлове филозофије (Berger, Luckmann 1992: 38). Занимљиво је да се оваквим теоријским решењем приближавамо и ставу до кога Нејтенсон долази када трага за одговарајућим позиционирањем Шицове теоријске концепције када је реч о филозофским и социолошким тенденцијама у његовом учењу. Говорећи о различитим „начинима на које је могуће успоставити алијансу између филозофије и друштвених наука", Нејтенсон закључује говор о феноменолошким основама Шицове социологије речима да су у оваквој концепцији „у својој теоријској основи, социологија и филозофија једно” (Natanson 1970: 120). 
Закључак - Шицова теорија допуњена „ставом феноменолошке филозофије” и „ставом филозофске теорије”?

Након разматрања улоге феноменолошког става у првом тому Шицових сабраних дела, може се закључити да је овај теоретичар заиста у извесној мери умањио значај који је Хусерл придао „стављању у заграде” и мишљењу да се њиме отвара н поље „трансценденталног искуства” којим се постављају темељи за феноменолошко филозофирање. Међутим, циљ сагледавања различитих Шицових текстова обједињених у овој књизи и начина на који се аустријски теоретичар опходи према овој тези Хусерлове филозофије не лежи у показивању да Шица не треба сматрати феноменолошки опредељеним мислиоцем или дискредитовању самог Шицовог учења као неконзистентног. Својеврсно етикетирање учења аустријског теоретичара као “феноменолошког” или “нефеноменолошког”, као и својатање његовог учења као “филозофског” или “социолошког” било би у супротности са Шицовим интердисциплинарним теоријским стремљењима. Разједињавање онога што је аустријски теоретичар обухватио у сопственој теорији неповољно би утицало и на учења његових следбеника, судећи по начину на који се Лукман односи према заговорницима „независне“ трансценденталне феноменологије, који би могли ниподаштавати теоријске ингеренције друштвених наука (Luckmann 1978: 168).

Насупрот томе, разматрањем Шицових теоријских решења које налазимо у књизи о проблему друштвене стварности и њихове повезаности са тезама Хусерлове феноменологије у овом раду смо најпре тежили одговарајућем позиционирању учења аустријског теоретичара унутар теоријског наслеђа феноменологије и њој сродних теоријских опредељења. Овакво позиционирање би могло допринети разумевању самих Шицових теза чак и у случајевима у којима се говори о оним аспектима његовог учења који су сасвим далеко од хусерловске концепције. Позиционирању Шицовог учења у историји феноменолошке филозофије бар у извесној мери доприноси разматрање начина на који се Шицово колебање у погледу феноменолошког наслеђа, испољено у преписци са Гурвичом, може пронаћи и у његовим кључним списима, попут текста о вишеструким стварностима. Са друге стране, указивањем на извесне разлике између Шицовог учења и прагматистичке оријентације, сугерисали смо да аустријски филозоф ипак остаје у домену утицаја који је на њега извршила Хусерлова феноменологија, независно од разлика које смо у раду истакли.

Међутим, изостанак тематизовања феноменолошког става у његовој теорији о вишеструким стварностима и „напетостима свести” уз помоћ којих се ове стварности доживљавају не сведочи само о месту које би аустријски филозоф заузео у неизбежно динамичном историјском развоју филозофије и социологије. Насупрот томе, оно указује и на извесна неразјашњена места у његовом учењу, чије би проблематизовање могло отворити пут ка занимљивим тумачењима самог Шицовог учења и додатном разрађивању ове концепције (налик оном које налазимо у теорији Бергера и Лукмана). Анализирајући и Нејтенсо- 
нову критику Шицове концепције, размотрили смо и извесне предности које би трансцендентални став могао имати у учењу аустријског филозофа, независно од чињенице да о њој не налазимо пуно речи у првом тому његових сабраних дела. Штавише, проналажење места за феноменолошки став у учењу Хусерловог следбеника помогло би у разрешавању извесних дилема када је реч о начину на који су у Шицовом учењу обједињене тенденције трансценденталне филозофије са теоријским тереном друштвених наука. Уколико се у тумачењу Шицове концепције дође до тога да се његовом теоријом о вишеструким стварностима може објаснити и његово сопствено феноменолошко филозофирање, тиме би се свакако афирмисао његов сопствени филозофски дискурс и његова тежња ка “верности” хусерловском наслеђу. Међутим, још је интересантније да би се на овај начин истовремено афирмисала и целовитост саме Шицове тезе о вишеструким стварностима и њима одговарајућим ставовима. Предложеном допуном, Шицово учење у тексту о вишеструким стварностима сачинило би пун круг од природног става и света свакодневног живота, до трансценденталног става као примарне алтернативе природном ставу у Хусерловом учењу.

Следствено томе, уколико би се у Шицовом учењу о вишеструким стварностима, уместо занемаривања трансценденталног става, пронашло место њему сличном ставу свести, проблем Шицовог амбивалентног односа према Хусерловој феноменологији би се могао додатно објаснити, а у извесном смислу и превазићи. Посебну мотивацију за такав подухват у раду смо добили захваљујући томе што аустријски филозоф и сам често спроводи теоретисање које је на трагу феноменолошке филозофије (а посебно у његовим анализама одређених аспеката Хусерловог учења, попут његовог решења проблема интерсубјективности). Зато би се, у контексту Шицовог говора о вишеструким стварностима, могло говорити о имплицитно присутном „ставу феноменолошке филозофије”, који, захваљујући хусерловској филозофији, већ има свој епохе. Самом Шицу не би била страна ни „напетост свести” која би овом ставу одговарала, нити њој одговарајући „когнитивни стил” (Шиц 2012: 290). Уосталом, сам Шиц је у тексту о вишеструким стварностима сугерисао да се његово учење о вишеструким стварностима може допунити на овај начин у тврдњама да је свет свакодневног живота ,један од многих" омеђених области значења, као и у речима да постоје „безбројне области” наше маште (Шиц 2012: 290291, 292). Други Шицови текстови у осталим томовима његових сабраних дела могли би у неком наредном раду пружити одговарајућу почетну тачку за трагање за таквим могућностима.

Излазећи из оквира говора о феноменолошком ставу и њему одговарајућег света, који већ и сам поседује многе од карактеристика Шицових алтернативних стварности, поменути предлог би се додатно могао проширити у неком наредном проучавању Шицове теоријске концепције. Имајући у виду да и сам Шиц спроводи сопствени теоријски дискурс у тексту о вишеструким стварностима, не утемељујући притом сам тај дискурс на некој посебној “стварности” и њој одговарајућој „напетости свести”, у неком будућем раду би се могло трагати и за општијим карактеристикама одређеног „става филозофске 
теорије” у Шицовом учењу. Тако би се начин на који Шиц обрађује филозофску проблематику у свом интердисциплинарном учењу могао размотрити и као посебан методолошки приступ, који се тек делимично ослања на традицију Хусерлове феноменологије.

\section{Литература}

Barber, Michael (2020) “Alfred Schutz", y: The Stanford Encyclopedia of Philosophy (Summer 2020 Edition), Zalta, Edward N. (yp.), https://plato. stanford.edu/archives/sum2020/entries/schutz. Приступ: октобар 2020. Berger, Peter L., Luckmann, Thomas (1992) Socijalna konstrukcija zbilje: rasprava o sociologiji znanja, Naprijed, Zagreb.

Cotkin, George (1985) "William James and the Cash-Value Metaphor" y: Etc: A Review of General Semantics Vol. 42.

Данси, Џонатан (2006) Увод у савремену епистемологију, Београд: Плато.

Dewey, John (1958) Art as Experience, New York: Capricorn Books.

Дјуи, Џон (1962) Логика, теорија истраживања, Београд: Нолит.

Eberle, Thomas S. (2012) „Phenomenology and Sociology: Divergent Interpretations of a Complex Relationship“, u: Interaction and Everyday Life: Phenomenological and Ethnomethodological Essays in Honor of George Psathas, Nasu, Hisashi Waksler, Frances Chaput (yp.), Lanham, Boulder, New York, Toronto, Plymouth: Lexington Books.

Embree, Lester (2020), „Alfred Schutz“, u: The Internet Encyclopedia of Philosophy, https://iep.utm.edu/schutz/. Приступ: октобар2020.

Gros, Alexis Emanuel (2017) “Alfred Schutz on Phenomenological Psychology and Transcendental Phenomenology" y: Journal of Phenomenological Psychology 48 (2017), стр. 214-239.

Hauser, Larry (2020) “Behaviorism”, y: The Internet Encyclopedia of Philosophy, https:// iep.utm.edu/behavior/. Приступ: октобар 2020.

Huserl, Edmund (1991) Kriza evropskih nauka i transcendentalna fenomenologija, Gornji Milanovac: Dečje novine.

Husserl, Edmund (1983) Ideas Pertaining to a Pure Phenomenology and to a Phenomenological Philosophy: First Book: General Introduction to a Pure Phenomenology, The Hague/Boston/Lancaster: Martinus Nijhoff Publishers.

Husserl, Edmund (1975) Kartezijanske meditacije, I, Zagreb: Centar za kulturnu djelatnost SSO.

Kim, Hongwoo (2005) „In Search of a Political Sphere in Alfred Schutz“, y: Explorations of the Life-World: Continuing Dialogues with Alfred Schutz, Endress, Martin, Psathas, George, Nasu, Hisashi (ур.), Dordrecht: Springer, стр. 203-234.

Luckmann, Thomas (1978) "Philosophy, Science, and Everyday Life", y: Phenomenology and Sociology: Selected Readings, Luckmann, Thomas (yp.), New York: Penguin Books, стр. 143-185. 
Натансон, Морис (2012а) „Увод“, у: Шиц, Алфред, Проблем друштвене стварности, Нови Сад: Mediterran Publishing.

Натансон, Морис (2012б) „Напомена уредника“, у: Шиц, Алфред, Проблем друштвене стварности, Нови Сад: Mediterran Publishing.

Natanson, Maurice (1970) „Alfred Schutz on Social Reality and Social Science“, y: Phenomenology and Social Reality: Essays in Memory of Alfred Schutz, The Hague: Martinus Nijhoff, стр. 101-121.

Nasu, Hisashi (1999) „Alfred Schutz's Conception of Multiple Realities Sociologically Interpreted“, y: Schutzian Social Science, Embree, Lester (yp.), Springer, Dordrecht, стр. 69-85.

Schutz, Alfred (1971) Collected Papers 1: The Problem of Social Reality, Natanson, Maurice (yp.), The Hague: Martinus Nijhoff.

Vaitkus, Steven (2005) “The 'Naturality’ of Alfred Schutz's Natural Attitude of the LifeWorld”, y: Explorations of the Life-World: Continuing Dialogues with Alfred Schutz, Endress, Martin, Psathas, George, Nasu, Hisashi (yp.), Dordrecht: Springer, стр. $97-$ 121.

Џемс, Вилјем (1940) Прагматизам, Београд: Космос.

Шиц, Алфред (2012) Проблем друштвене стварности, Нови Сад: Mediterran Publishing.

Wozniak, Robert H. (1993) "Introduction" y: Theoretical Roots of Early Behaviourism: Functionalism, the Critique of Introspection, and the Nature and Evolution of Consciousness, Wozniak, Robert H. (yp.), London: Routledge/Thoemmes Press.

Dušan Milenković

\section{THE ROLE OF PHENOMENOLOGICAL ATTITUDE IN ALFRED SCHUTZ'S COLLECTED PAPERS I: THE PROBLEM OF SOCIAL REALITY}

Abstract: In this paper, the thought of the Austrian-born theorist Alfred Schutz, presented in the articles published in the first volume of his collected papers, is examined from the perspective of the role that Edmund Husserl's phenomenological attitude plays in it. Advocating the importance of analyzing the structure of the world of everyday life in his phenomenology of the natural attitude, Schutz uses various aspects of Husserl's phenomenology, without paying special attention to the phenomenological attitude itself. Therefore, the paper discusses the extent to which Schitz's understanding of the natural attitude and its world depends on this concept of Husserl's philosophy, with special reference to Shutz's theory in his article "On Multiple Realities". After showing that Husserl's phenomenological attitude cannot be compared to the "attitude of scientific theory" discussed in the article on multiple realities, the paper additionally analyzes the absence of the phenomenological attitude in Schutz's thought while turning to Maurice Natanson's critique of Schutz's theory. Furthermore, the paper 
discusses the extent to which the Austrian theorist is inspired by pragmatic philosophy in his distancing from the transcendental phenomenology. Finally, a certain solution to the problem of the appropriate status of phenomenological philosophy in Schitz's theory is found in Thomas Eberle's views on Thomas Luckmann's distinction between phenomenology and sociology. The paper concludes by considering the possibility of the "attitude of phenomenological philosophy" in Schitz's system of multiple realities.

Keywords: Alfred Schitz, phenomenology, natural attitude, phenomenological attitude, Edmund Husserl, Collected Papers I: The Problem of Social Reality 